\title{
Syntactic Analysis of Language Acquisition in Three-Year-Old Children Based on Cultural Background
}

\author{
Nur Lailiyah $^{1}$ \\ Universitas Nusantara PGRI Kediri \\ Intan Prastihastari Wijaya ${ }^{2}$ \\ Universitas Nusantara PGRI Kediri
}

DOI: https://doi.org/10.21009/10.21009/JPUD.131.05

Accepted: $15^{\text {th }}$ March 2019. Published: $30^{\text {th }}$ April 2019

\begin{abstract}
The variety of languages and cultures in the community will indirectly affect the acquisition and development of children's language. This will be seen when children change residence, where new dwellings, different variations or dialects. At the PAUD Nusantara University School Laboratory PGRI Kediri, most children from various regions, they are migrant families in the city of Kediri and need adaptation in the new environment including the language. This study uses a qualitative descriptive approach, the purpose of which is to describe the acquisition of language of three-year-olds in terms of cultural background and to describe the average length of speech of threeyear-olds based on Mean Length of Utterance (MLU). The research subjects were four children from Tulungagung, Kediri, Malang and Surabaya. The results of speech analysis show that the average research subjects from Tulungagung, Malang, Kediri and Surabaya had an average MLU of 2.92 in stage VI, which meant that they were still at a low stage, which at the age of three was already at the stage VII 3.0-3.5 words per speech. Based on the results of the analysis, it is recommended that teachers and parents improve stimulation and find appropriate strategies for the acquisition and development of children's language.
\end{abstract}

Keywords: Acquisition of children's language, Cultural background, Syntax Analysis

(C) 2019 Early Childhood Education Post Graduate Program UNJ, Jakarta e-ISSN (Online Media) : 2503-0566

P-ISSN (Print Media) : : 1693-1602

\footnotetext{
${ }^{1}$ Corresponding Author:

Nur Lailiyah

Universitas Nusantara PGRI Kediri

Jln. KH. Ahmad Dahlan No. 76, Mojoroto, Kota Kediri, Jawa Timur, Indonesia

Email: lailiya86@unpkediri.ac.id
} 


\section{INTRODUCTION}

Every child has the development of different language skills, starting from early age to adulthood. Starting from the simple to the most complex. Variations can be observed at each level of description ranging from individuals to social especially in the skills of language (Seamus \& Morten, 2018). Children learn languages more easily than adults (Hartshorneab, Tenenbauma, \& Pinker, 2018). The development of a child's language skills will increase with age and the stimulus that children get (Hetherington, 2003).

Language skills are the result of a combination of all children's development systems, because language skills are sensitive to slowness or damage to other systems. Language skills increase as the brain develops. Language processing, especially understanding complex sentences, is supported by brain tissue (Qia et al., 2019). Language skills involve motor, psychological, socialemotional abilities. When getting a language, the child is faced with a challenge to decode relationships between certain greeting entities, which require certain grammatical sayings and the thematic roles played by each entity. So that this can be done, the child must implement it linguistic cues and regularities provided by certain languages (Vissiennon, Friederic, Brauer, \& $\mathrm{Wu}, 2016$ ). Language mastery can be seen as a type of mastery of skills, just as in learning to ride a bicycle, play a musical instrument, or draw; and the need to gain knowledge about the abstract structure of language (Chater \& Christianshen, 2018).

Communication patterns of children aged 2-3 years experience rapid language development. In the age of 2 years most children can follow simple instructions or instructions. Children aged 3-6 years have obtained vocabulary, namely basic vocabulary (nouns, verbs, adjectives, number words, pronouns, words related to kinship, and prepositions), derivative vocabulary (prefix suffixes, suffix suffixes, affixes infix, and confix inflations), and vocabulary (Smith, 2010). After hearing the first words of sentences, toddlers can properly exploit prosodic information to access the syntactic structure of sentences to help determine the syntactic categories of ambiguous words and to correctly identify the intended meaning (Carvalho, Dautriche, \& Lind, Christophe, 2017). Three year-old children represent abstract sentences, have syntactic representations for nouns, verbs, "surface subjects", and "surface objects", have semantic representations for "agents" and "patients", and flexibly map out the relationship between syntax and semantics (Thothathiri \& Snedeker, 2008); (Giulia \& Virginia, 2008).

Children's social ability is related to the ability to manage their emotion with others that are related to heart and to care each others so that children can interact well with peers or with adults in the surrounding environment (Darjowidjojo, 2010). The ability to interact is inseparable from the acquisition of language that is mastered by children. Many factors influence the acquisition and development of children's language, namely internal and external factors (Sumarsono \& Partana, 2018). External factors came from outside the child, one of the external factors is the family and school environment. Children get and understand the sound of the right language and can listen well from their family. The family is informal education and the closest environment to the child. While the school is a formal education where children get a second language and transfer experience gained from the family environment (Rahardi, 2001).

The environment has an important role in children's language development. Children's language varies according to its nature, as well as the environment around children and based on that environment their culture is built (Chaer, 2003). Diverse cultures will influence the acquisition of children's language (Chaer \& Agustina, 2004). Social and cultural factors also determine a child's 
success or failure in language acquisition (Muhlhausler, 2010). so that every child has the characteristics and distinctive language that other children do not have, which is why the differences between individuals are created.

Children acquire language from their cultural environment through imitating the language they hear, and bring it to the school environment (Sumarsono, 2013), so that even though the child controls dozens of words but the child has not been able to use the words maximally, the child only uses a few words communicate with friends at school. This is due to the fact that some children have different cultures so that they need new adaptations and similarities in the understanding of language in their schools, similar things are also found in previous studies that local language culture or environment can inhibit the acquisition of children's language (Hakim, 2016).

Child language acquisition is associated with the acquisition of syntax. One language development that is typically experienced by children is syntactic development. In the initial period the child uses one-word sentences, two-word sentences, three-word sentences, and so on until the complete sentence stage structure. In general, three-year-olds develop syntax at different stages, while words that contain meaning in the sentence uttered by a child can be measured by the Mean Length of Utterance or MLU. MLU is a concept used to measure linguistic products produced by children (Roni, 2016). Four factors that influence the syntax acquisition of children aged two years and three years are natural factors, cognitive development factors, social background factors and heredity; intelligence and language mastery style (Hutabarat, 2018).

Language acquisition as a process takes place in the brain of children, is obtained from their first language or his native language. Language acquisition is usually distinguished from language learning. Language learning is related to the processes that occur in children learning a second language after he learns his first language. Thus, language acquisition is related to first language acquisition (B1), while learning language is related to the second language (B2) when children interact with their environment. Vocabulary that can be mastered by children aged 3-6 years is the basic vocabulary (nouns, verbs, adjectives, number words, pronouns, words related to kinship, and prepositions), derivative vocabulary (prefix suffix, suffix suffix, affix infix, and confix inflations), and vocabulary (Salnita, Atmazaki, \& Abdurrahman, 2019).

The MLU calculation is done by dividing the morpheme number with the utterance number. The higher the child's MLU, the higher the language's mastery of the child. But the reality in the field is not all three-year-old children have high MLU, as in children at PAUD Nusantara University School Laboratory PGRI Kediri comes from families who have different backgrounds, so that when interacting with schools with peers is still difficult. In line with the research, that the incompatibility of the results of this MLU can be influenced by differences in children's language environment, the higher the ability to interact, the higher the value of the MLU. Whereas from the research conducted by (Bachri \& Maya, 2012) showing that there is a delay in stimulating children will greatly affect the acquisition of language and calculation of children's MLU.

MLU is a tool to measure the development of child syntax. MLU was first discovered by Roger William Brown (14, April 1925 - 11, December 1997) a social psychologist from America. Brown said how to calculate MLU could be done in several steps. First, take a sample of 100 utterances. Second, calculate the number of morphemes. Third, divide the number of morphemes by the number of utterances. Signs used are for example, the form of compound (train), irregular verbs (drank), and plural irregular (children) are considered one morpheme. pay attention to the following MLU formula: 


$$
\text { MLU }=\frac{\text { Number of Morphemes }}{\text { Number of Utterance }}
$$

Brown divides the stages of children's language acquisition based on children's MLU into ten stages (Owens, 2008), namely:

Table 1 MLU Stages According to Brown

\begin{tabular}{cccc}
\hline No & Stage & MLU & Age/Month \\
\hline 1 & I & $1-1,5$ & $12-22$ \\
2 & II & $1,5-2,0$ & $27-28$ \\
3 & III & $2,0-2,25$ & $27-28$ \\
4 & IV & $2,25-2,5$ & $28-30$ \\
5 & V & $2,5-2,75$ & $31-32$ \\
6 & VI & $2,75-30,0$ & $33-34$ \\
7 & VII & $3,0-3,5$ & $35-39$ \\
8 & VIII & $3,5-3,45$ & $38-40$ \\
9 & IX & $3,5-3,45$ & $41-46$ \\
10 & X & $45+$ & $47+$ \\
\hline
\end{tabular}

In this study, the focus is on calculating the MLU language of three-year-olds who have different cultural backgrounds, namely children from Surabaya, Malang, Tulungagung and Kediri.

The results of the study are expected to contribute to the development of the science of early childhood education, especially with regard to the acquisition of children's language from various cultural backgrounds, so that it becomes a reference for teachers in developing strategies for children's language acquisition and for parents to increase stimulation in efforts to increase children's vocabulary acquisition.

\section{METHODS}

This study uses a qualitative descriptive approach, which aims to understand the phenomenon of what is experienced by the subject of research such as speech, the length of the short speech (utterance of one word, two words, and so on). The object of this research is the utterance of threeyear-olds of different cultural backgrounds and will be studied through syntax. This study uses a modification of the Creswell model. (Creswell, 2012) suggests several characteristics of the Research Field namely: Stage I: Include data collection; open-ended interview , direct observation, participant observation, Phase II: Data analysis, Phase III: Data collection, Phase IV: Data analysis, and Stage V: Analyst's overall interpretation.

This research was conducted at PAUD Nusantara University School Laboratory PGRI Kediri. Whereas the execution time starts in March 2018 until July 2018. Recording is done naturally, meaning that the researcher does not make any inference, children are left to speak naturally in places not specifically provided. The research subject in question is four three-year-old children with a maximum of three months adrift.

The data source for this study was four children aged three years and each had a maximum of three months adrift. The language used by the child is a mixed language between Indonesian and Javanese but with several Javanese dialects (Tulungagung), Java (Malang), and Java (Kediri) and Java (Surabaya). The language is his first language or his native language. The data referred to in this study were the acquisition of language from the four children of PAUD Nusantara School 
Laboratory PGRI Kediri University, the data were obtained through observation, recording and completed field notes. According to (Mahsun, 2005) the basic technique is used as the implementation of proficient methods if the researcher provides stimulation (inducement) to the informant to bring up linguistic symptoms expected by the researcher. The data analysis technique in this study uses data triangulation techniques. Data analysis technique, according to (Moleong, 2007) analysis of data is the process of organizing and sorting data into patterns, categories, and basic units of description so that themes can be found, and work hypotheses can be formulated. In data analysis techniques not only do data collection and data compilation, but also interpret the meaning of existing data.

The linguistic aspects in this study analysed were syntax of children's language acquisition. The analysis will be carried out qualitatively and quantitatively. The quantitative method involves analysing the distribution and estimation of the MLU as a method that determines the child's language development. Analysing data can be done in four steps, namely: (a) Speeches recorded through diaries and recordings are transcribed in sentences. The collected data is arranged in the form of the structure of the child's speech sentence. (b) Data Selection has been transcribed is processed by separating the data needed and fulfilling the requirements that are in accordance with the research objectives. selected children's speech is speech that meets the requirements of the study and can be calculated by the MLU. (c) Data Classification has been selected is in accordance with the research objectives and data that can be calculated by the MLU. How to classify the data is by grouping children's speech based on the number of morphemes in each speech. Furthermore, the number of morphemes for each speech is summed (the number of speeches is limited to only 100 utterances). Then, the number of morphemes from 100 utterances is divided by 100. (d) Presentation of Data Analysis Results, after knowing the results of the MLU, the results were analysed to find out the average MLU of the three-year-old child who was the research sample at what stage and analyse the acquisition of syntax in terms of speech length and sentence structure.

\section{RESULT AND DISCUSSION}

The results of data collection for three-year-old are as follows:

Data transcripts of 100 words of research subjects (SP), the data below has gone through the process of classifying and transliterating into Indonesian.

\begin{tabular}{|c|c|c|c|c|}
\hline $\begin{array}{c}\text { Number of Words } \\
\text { per Test }\end{array}$ & $\begin{array}{l}\text { Research } \\
\text { Subject I }\end{array}$ & Research Subject II & Research Subject III & $\begin{array}{c}\text { Research Subject } \\
\text { IV }\end{array}$ \\
\hline $\begin{array}{l}\text { One-word sen- } \\
\text { tence }\end{array}$ & $\begin{array}{l}\text { Eat, rice, stuffed, } \\
\text { ship, play, study, } \\
\text { participate in a race, } \\
\text { angry, happy, car, } \\
\text { pan, open, book, } \\
\text { dance, sing, deli- } \\
\text { cious, melon, grand- } \\
\text { father, balloon, } \\
\text { erupt, school, mate, } \\
\text { bag, candy, ma, run, } \\
\text { run, kucing, black, }\end{array}$ & $\begin{array}{l}\text { Holiday, play, train, } \\
\text { eat, drink, chair, ta- } \\
\text { ble, crap, Miss, } \\
\text { mama, ka-sis, join, } \\
\text { swim, burger, bicy- } \\
\text { cle, bin, hand, } \\
\text { swing, together, } \\
\text { naughty, no, sick, } \\
\text { milk, sing, fall, run, } \\
\text { Alin, ask, buy, get } \\
\text { out, pants }\end{array}$ & $\begin{array}{l}\text { Drink, milk, bread, } \\
\text { fly, bird, eat, cake, } \\
\text { follow, An-ti, } \\
\text { chicken, stone, fried, } \\
\text { hot, rice, egg, take, } \\
\text { aunt, vegetable, like, } \\
\text { no, sun, home, school, } \\
\text { leave, alone, standing, } \\
\text { scared, snake, me, } \\
\text { clothes, forget, } \\
\text { naughty, call, fall, }\end{array}$ & $\begin{array}{l}\text { Snack, rain, star, } \\
\text { lightning, milk, } \\
\text { lazy, play, learn, } \\
\text { cry, beat, swing, } \\
\text { shoes, new, drink, } \\
\text { carry, brown, eat, } \\
\text { fruit, like, play, ball, } \\
\text { Miss, Mama, take, } \\
\text { Uzan, vegetables, } \\
\text { swings, sweet }\end{array}$ \\
\hline
\end{tabular}




\begin{tabular}{|c|c|}
\hline & $\begin{array}{l}\text { brother, miss, fall, } \\
\text { rope, leg, fish, egg, } \\
\text { drink, green, me, } \\
\text { song }\end{array}$ \\
\hline $\begin{array}{l}\text { Two word sen- } \\
\text { tence }\end{array}$ & $\begin{array}{l}\text { Drinking water, } \\
\text { learning to sing, } \\
\text { cats, cats, ships, } \\
\text { Miss angry, eating } \\
\text { melons, hi-jau bags, }\end{array}$ \\
\hline & $\begin{array}{l}\text { Miss singing, } \\
\text { grandma going, eat- } \\
\text { ing rice, wearing } \\
\text { clothes, barbie dolls, } \\
\text { playgroup schoo,, } \\
\text { grandfather's eyes, } \\
\text { balloons erupted, } \\
\text { her cat ran away, } \\
\text { Miss fell, played a } \\
\text { rope, the eggs were } \\
\text { delicious, her desk } \\
\text { was black, her cat } \\
\text { was a kit, followed } \\
\text { her, grandpa, sick, } \\
\text { black car }\end{array}$ \\
\hline
\end{tabular}

Three One word The cat ran away, sentence

Four One word sentence

push, book, sleep,

fruit

Play the train, eat burgers, dedek chairs, play swings, drink milk, play bicycles, take a vacation, ask for stars, Miss sing, Ditto pants, fall down, buy a train, play outside, buy a burger, hurt hands, join Miss

Play the train, Miss eat the burger, this is the dedek chair, go to the deck to play the swing, drink Miss milk, brother play the bike, take a break from school, ask Miss Miss, Miss sing my balloon, dirty pants, drop Miss, buy a train tuttut, playing out there, buy a good burger, my hands hurt, want to come Miss, dare to sleep alone, the toy plane, when to come home Miss, how many birds are Miss, I don't want to

Play the train tut, I like to eat vegetaMiss wants to eat a bles, want to go to burger, this chair belongs to Dedek, dedek want to play
Like vegetables, go alone, fly birds, drink milk, eat bread, go to school, fried chicken, afraid of chickens, fried chicken, fear of snakes, eat cakes, join Anti, aunt is afraid, likes cakes, my shirt is new, my bag, this is my desk, hot Miss, don't know

I like vegetables, I want to go alone, people fly there, drink stowberry milk, eat chocolate bread, go to school together, tasty fried chicken, fear of chicken, want fried chicken, fear of snakes Miss, eat cakes again, eat cake again, want to join Anti, Aunt here, I play swing, want to pee Miss, ask for a five star school on my own, birds fly there Miss, I drink stowberry milk,
New shoes, Ayan play, chocolate milk, rain again, want to snack, like fruit, uzan swing, Ayan cry, eat fruit, play bo-la, mama inter, su sweet, ask for stars, there is lightning, bring drink, lazy play, Uzan learns
Have new shoes, Ayan plays football, drinks chocolate milk, Miss rain again, wants to buy snacks, doesn't like fruit, uzan plays swing, Ayan cries Miss, eats bananas, wants to play football, mama between Ayan, milk is sweet, ask for stars again, watch out for lightning, take drinking Ayan, Ayan lazy to play, Uzan learns Miss

I have new shoes, I play football myself, drink chocolate milk Miss, Miss rain again, you want to 
to throw puppies, swing, drink su su

Five word sentence sister asking for sweets Miss, Do not want to play together, do not want to learn Miss,

Miss, brother wants to play bicycle, ask for three stars Miss, Miss want to sing my balloon, dirty dirty pants Miss,

Today I eat fried rice, I woke up today, I was angry at my brother, I have toy cars, I want to buy candy boy-boy, you don't ask for my candy, I don't want to color Miss. want to eat chocolate bread, go to school with my brother, fried chicken is delicious Miss, afraid of afternoon cock, want fried chicken now, want to eat cake again, I just ate bribed, my mother was angry about me, I played a lot of Miss

I like to eat vegetables Miss, want to go to school by myself now, catch birds fly there Miss, I drink this Strawberry milk, want to eat chocolate bread and strawberry, go to school with my brother, yeah, this fried chicken tastes good Miss, do not want to color now Miss, eat later at home again, dedek want to join mama miss buy taro snacks, don't like to eat fruit, uzan wants to play swing, Ayan cries again Miss, Uzan eats bananas, wants to play football mama between Ayan school

I have two new shoes, Udin wants to play his own ball, drink chocolate milk again Miss, Miss rain again outside, want to buy taro snacks Miss, don't eat pi-sang fruit, uzan wants to play his own swing

\subsection{Research Subject I from Tulungagung}

Table 5.1. Number of utterances

\begin{tabular}{ccc}
\hline $\begin{array}{c}\text { Number of words } \\
\text { utterance }\end{array}$ & $\begin{array}{c}\text { Number of } \\
\text { utterance }\end{array}$ & $\begin{array}{c}\text { Number of } \\
\text { morphemes }\end{array}$ \\
\hline One-word sentence & 43 & 41 \\
Two-word sentence & 25 & 50 \\
Three-word sentence & 22 & 66 \\
Four-word sentence & 19 & 76 \\
Five word & 11 & 55 \\
Total & 120 & 288 \\
\hline
\end{tabular}

From the data above, SP I which is three years and more than one month old can say 120 speech words or 288 morphemes. The data shows that SP I is able to express one-word sentences as many as 43 words, two-word sentences as many as 25 words, three-word sentences as many as 22 words, four-word sentences as many as 19 words and five-word sentences as many as 11 words, while the length of sentences that SP can say I have a maximum of five morphemes. SP I originating from the Tulungagung area, has its first language (B1) in the Javanese language of Tulungagung 
dialect and its second language (B2) in Indonesian, so that when SP 1 learns in formal schools in the City of Kediri, when interacting with friends it will experience obstacles in processing acquisition language. Children acquire native language through exposure to language related to structured representations that can be associated with words and syntactic structures used to express a concept (Abend, Kwiatkowski, Smith, Steedman, \& Sharon, 2017). If SP 1, B1 uses the Javanese language of Tulungagung dialect, then when the SP moves in the city of Kediri, the PB will be hampered by the $\mathrm{B} 1$ Tulungagung accent and the B1 accent of Kediri so that the development of language acquisition is still in the range of 288 morpheme.

\subsection{Research Subject II from Malang}

Table 5.2. Number of utterances

\begin{tabular}{ccc}
\hline $\begin{array}{c}\text { Number of words } \\
\text { utterance }\end{array}$ & $\begin{array}{c}\text { Number of } \\
\text { utterance }\end{array}$ & $\begin{array}{c}\text { Number of } \\
\text { morphemes }\end{array}$ \\
\hline One-word sentence & 35 & 35 \\
Two-word sentence & 25 & 50 \\
Three-word sentence & 26 & 78 \\
Four-word sentence & 21 & 84 \\
Five-word & 9 & 45 \\
Total & 116 & 292 \\
\hline
\end{tabular}

From the data above, SP II which is three years old can say as many as 116 words of speech or 292 morphemes. The data shows that SP II is able to express one-word sentences of 35 utterances, two-word sentences of 25 utterances, three-word sentences of 26 utterances, four-word sentences of 21 utterances and five-word sentences of nine utterances, while the length of sentences that SP can say II a maximum of five morphemes. SP II originating from the city of Malang, has its first language (B1) in the Javanese language of Malang accent and its second language (B2) in Indonesian, so that when SP 1 studies in formal schools in the City of Kediri, when interacting with friends it will experience processing problems language acquisition. If SP II, B1 uses the Javanese dialect of Malang, then when the SP moves in the city of Kediri the PB will be hampered by B1 Malang accent and B1 Kediri accent so that the development of language acquisition is still in the range of 292 morphemes, which are not far from SP I from Tulungagung.

\subsection{Research Subject III from Kediri}

Table 5.3. Number of utterances

\begin{tabular}{ccc}
$\begin{array}{c}\text { Number of words } \\
\text { utterance }\end{array}$ & $\begin{array}{c}\text { Number of } \\
\text { utterance }\end{array}$ & $\begin{array}{c}\text { Number of } \\
\text { morphemes }\end{array}$ \\
\hline One-word sentence & 39 & 39 \\
Two-word sentence & 33 & 66 \\
Three-word sentence & 29 & 87 \\
Four-word sentence & 18 & 72 \\
Five word & 11 & 55 \\
Total & 132 & 319 \\
\hline
\end{tabular}


From the data above, SP III which is three years and more than one month old can say 132 spoken words or 319 morphemes. The data shows that SP III is able to express 39 words of one word sentence, 33 words of two words, 29 words of three words, four words of sentence are 18 words and sentence of five words is 11 words, while the length of sentence can be SP. III a maximum of five morphemes. SP III originating from the city of Kediri, has its first language (B1) in the language of the Javanese dialect of Tulungagung and its second language (B2) in Indonesian, when the SP III studies in formal schools, when interacting with friends even though the area of residence is different but language dialect, it will also experience problems in processing language acquisition. Judging from table 5.3, the acquisition of 319 morphemes is more than that of the Tulungagung, Malang, and Surabaya regions.

\subsection{Research Subject IV from Surabaya}

Table 5.4. Number of utterances

\begin{tabular}{ccc}
\hline $\begin{array}{c}\text { Number of words } \\
\text { utterance }\end{array}$ & $\begin{array}{c}\text { Number of } \\
\text { utterance }\end{array}$ & $\begin{array}{c}\text { Number of } \\
\text { morphemes }\end{array}$ \\
\hline One-word sentence & 39 & 39 \\
Two-word sentence & 28 & 56 \\
Three-word sentence & 23 & 69 \\
Four-word sentence & 15 & 60 \\
Five word & 8 & 40 \\
Total & 113 & 264 \\
\hline
\end{tabular}

From the data above, SP IV which is three years and two months old can say 113 spoken words or 264 morphemes. The data shows that SP IV can express 39 words in one sentence, 28 words in two words, 23 words in three words, 15 words in four words and eight words in five words, while the length of sentence can be SP. IV maximum of five morphemes. SP IV originating from the Surabaya area, has its first language (B1) in Indonesian and its second language (B2) in a foreign language, so when SP IV studies in formal schools in the Kediri City area, when interacting there will be problems in processing language acquisition. If SP 1, B1 uses Indonesian, then when the SP moves in the city of Kediri then PB-2 can be the language of the Javanese dialect of Kediri, the existence of this will certainly hinder the acquisition of both languages (PB 2), so that SP IV can only obtain a range of morphemes 264 morphemes

\subsection{Test Measurements with Mean Length Utterance (MLU)}

The formula for calculating children's utterances is:

$$
M L U=
$$

Number of Morphemes

Number of Utterance

SP I

$M L U=\frac{\text { Number of Morphemes }}{\text { Number of Utterance }}=\frac{283}{100}=2,83$


From the measurement of MLU above SP I, those aged three years and over one month have an MLU that is currently in stage VI. SP I come from Tulungagung which has B1 in Javanese.

\section{SP II}

$$
M L U=\frac{\text { Number of Morphemes }}{\text { Number of Utterance }}=\frac{292}{100}=2,92
$$

From the measurement of MLU above SP II, those who are three years old have an MLU that is currently in stage VI. SP I come from Malang which has B1 in Javanese

$$
\text { SP III }=\frac{\text { Number of Morphemes }}{\text { Number of Utterance }}=\frac{319}{100}=3,19
$$

From the measurement of MLU above SP III, three years old has a high MLU and is in stage VII. SP I come from Kediri which has B1 in Javanese.

\section{SP IV}

$$
\begin{aligned}
& \text { Number of Morphemes } \quad 278 \\
& M L U=
\end{aligned}=2,78
$$

Number of Utterance $\quad 100$

From the measurement of MLU above SP IV those who are three years and two months old have an MLU that is (-) and is in stage VI. SP IV comes from Surabaya which has B1 in Indonesian.

\subsection{Analysis Based on Language Acquisition}

First language acquisition, children are also able to compile sentences even though they are still very simple. In terms of logic, sentences are defined as utterances that convey complete thoughts composed of subjects and predicates. Understanding that the subject is about what something is said, and predicate is what is said about the subject, which needs to be considered is that the term subject and predicate refers to function, not to the type of word. Note the following footage of SP IV conversations that are three years and two months old:

$\begin{aligned} \text { SP IV } & \text { :I want to snack } \\ \text { PP } & \text { :Yes later, you haven't taken a break } \\ \text { SP IV } & \text { :Don't want to } \\ \text { PP } & \text { :Yes. patiently completed first color it } \\ \text { SP IV } & \text { :Don't want it } \\ \text { PP } & \text { :You can't get a star later } \\ \text { SP IV } & \text { :Nothing }\end{aligned}$


From the conversations above SP IV originating from the city of Surabaya which have MLU 2.64 appear to answer questions with simple sentences, SP IV more often uses two-word sentences with the pattern KKVK + KVV and KKVK + VKV. SP IV, which has a first language, Indonesian seems to be a process of self-adjustment as well as the language that it hears, so the sentence spoken is very simple and from the syntactic level it is still in the two-word utterance

Pay attention to the three-year old SP I conversation:

PP : Why are you crying?

SP I : Where is Mommi, Miss?

PP : Later you will be picked up from school

SP I : want to come with mommi, now!

PP : Mama is still on the trip

SP I : I want to go home

PP : Come on now we play again

From the conversation above SP I originating from Tulungagung which has MLU 2.88, it seems dominant to use a sentence in the form of a statement, SP I more often uses three-word sentences with the pattern KVKV + KVKV + KVKK and VKV + KVV + KVKVKK. SP I, which has a first language, Javanese does not seem to experience difficulties in interacting even though it is still in the process of adjusting in a new environment that has a new accent, so the sentences spoken are more complete than SP 1 and from the syntactic level they are still in the utterance three words.

Note the footage of SP II conversations that are three years and two months old

$$
\begin{array}{ll}
\text { PP } & : \text { Want to play cars? } \\
\text { SP II } & : \text { Want it, but it's broken? } \\
\text { PP } & : \text { Here, Miss corrected } \\
\text { SP II } & : \text { Can be alone } \\
\text { PP } & : \text { Yes } \\
\text { SP II } & : \text { How come it can't } \\
\text { PP } & : \text { Come on here, I help you }
\end{array}
$$

From the conversation above SP II originating from Malang City which has MLU 2.92 the dominant uses three-word sentences, even though the MLU value is higher than SP II and SP II, but it has not been maximized in the use of the sentence.

The pattern used by SP II is KVK + CVCV + CVCVK and KVK + KKVK + CVKV. In the sentence that is spelled out SP II seems to have a level, syntax is in the three-word utterances as well as SP I, but the SP II of the resulting speech is more active-critical, whereas in SP II the spoken speech tends to be active-passive.

Pay attention to the footage of SP III conversations that are three years and one month old:

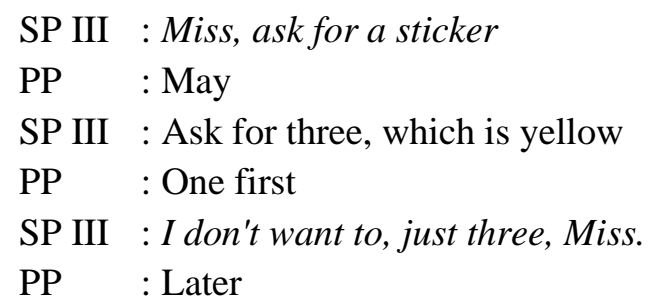


From the conversation above SP III originating from Kediri which has MLU 3.19 it seems active to use sentences in the form of commands, SP III more often uses four-word sentences with $\mathrm{KVKKV}+\mathrm{KVKV}+\mathrm{KVKK}+\mathrm{KVKKV}$ and KKVK + KVV + KVKVKKV + KVKV + KVKK, Footage in the utterances of the four SP above, can be proof that three years old children can already use sentences. The sentences that are usually pronounced are still very simple but can stand as sentences. Orally the words spoken by SP can be said as sentences, because sentences in spoken language begin with silence interrupted by pauses and end silence as well.

The four SP have different levels of MLU, with heterogeneous members of a speech community and various cultures in the family environment being an influence on stimulation of children's language acquisition. When the stimulation and habituation of the language obtained by the child is enough, there is no obstacle in the acquisition of children's vocabulary, so it is not difficult for children to interact in the language environment. But conversely if child stimulation is not enough then this becomes an obstacle for children when interacting in society, he will tend to become an active listener without understanding the meaning of the language he hears.

Understanding of the language that is heard also greatly influences the acquisition of children's language, especially in the language environment that children have a culture that is different from the language environment at home. So that when interacting with friends and the community environment children will tend to take longer vocabulary absorption, this is because the child will tend to think of the meaning of the language he just heard.

\subsection{Average Test Length Analysis}

From the data that has been obtained, transcribed, selected, and classified, it is analyzed to find out the number of children's utterances calculated with the Mean Length Utterance (MLU), then the last to find out the average MLU of the child is calculated through the formula below:

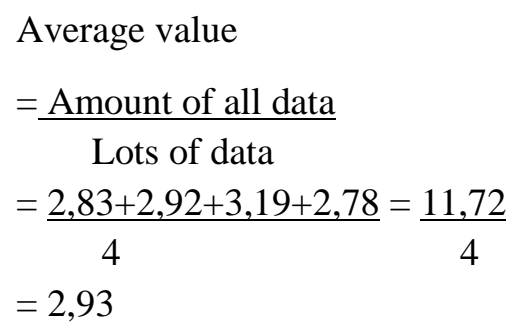

Based on the results of the MLU measurements above, the average length of speech of children is 2.93. When adapted to Brown's opinion (in Owens, 2008), fourth the subject of the study is still in stage VI, which means that the acquisition of children's language at PAUD Laboratory School is still low because at three years of age it is generally in stage VII 3.0-3.5 words per speech. There are two processes that will occur when the child is getting his first language (PB 1), namely the process of competence and process performance (understanding and language products produced). Both processes have different meanings. Competence is a process in grammar mastery that takes place unconsciously, so it becomes a condition for the process of performance (understanding and production of language). The process of understanding involves the ability to perceive sentences that are heard. While the process of producing sentences involves the ability to produce sentences themselves. Of the four research subjects already have a vocabulary that is qualified in language acquisition, but is still constrained in the process of understanding the 
language that is heard so that it influences the process of performance or language products. Based on this, the teacher must understand that the process of acquiring word meanings in the language of 3-year-olds has five symptoms of semantic word transition, namely symptoms (1) excessive specifications, (2) excessive generalization, (3) overlapping, (4) towards specifications meaning, and (5) the use of meaning associations. The development of the acquisition of word meanings by children along with the development of maturity of cognition, knowledge and experience, and vocabulary in children (Nurjamiaty, 2015).

\section{CONCLUSION}

Language acquisition of three-year-old children from Tulungagung aged three years as many as 120 speeches and 288 morphemes, from Malang aged three years and over one month as many as 116 speeches and 292 morphemes, from Kediri over three years old as many as 132 speeches and 319 morphemes, while from Surabaya three years and two months as many as 113 speeches and 264 morphemes. While speech analysis shows that the average research subjects from Tulungagung, Malang, Kediri and Surabaya have MLU 2.92 in stage VI, which means they are still at a low stage, which at the age of three is already in stage VII 3.0-3.5 word per utterance. However, it must be admitted that the acquisition of children's language does not always have to be the same, because every child has different abilities in language acquisition, depending on the stimulation of the language the child obtains in the cultural environment in which the child lives.

Parents, educators are expected to be active, caring and synergizing in helping to develop children's abilities in the acquisition of language by providing as much and as varied stimulation as possible, so that children will not experience difficulties when children interact in society. Parents and educators are expected to be more creative in stimulating language, so that language development in children can be optimized or as expected. From the point of the research, it is expected that educators who have students from several regions are expected to develop strategies in the development of early childhood language acquisition.

\section{REFERENCES}

Bachri, C., \& Maya, R. (2012). Pemerolehan Bahasa Anak Usia 7 Tahun 3 Bulan dalam bidang Sintaksis. Jurnal Edukasi Kultural.

Chaer, A. (2003). Psikolinguistik: Kajian Teoritik. Jakarta: PT Rineka Cipta.

Chaer, A., \& Agustina, L. (2004). Sosiolinguistik Perkenalan Awal. Jakarta: PT Rineka Cipta.

Chater, N., \& Christianshen, H. M. (2018). Language acquisition as skill learning. Behavioral Science.

Creswell, J. C. (2012). Introduction to Research Methods in Education. Los Angeles: Sage Publication.

Darjowidjojo, S. (2010). Psikolinguistik (Pengatar Pemahaman Bahasa Manusia). Jakarta: Yayasan Obor Indonesia.

Hakim, U. (2016). Studi Pemerolehan Bahasa pada Anak Usia 4 tahun (Kajian Sintaksis). Jurnal Linguistik Terapan.

Hetherington, P. (2003). Psikologi Perkembangan Anak dan Remaja Terjemahan Soemitro. Jakarta: Universitas Indonesia.

Hutabarat, I. (2018). Pemerolehan Sintaksis Bahasa Indonesia Anak Usia Dua Tahun Dan Tiga Tahun Di Padang Bulan. Jurnal Dharma Agung, Xxvi(1). 
Mahsun. (2005). Metode Penelitian Bahasa. Jakarta: PT Raja Grafindo Persada.

Moleong, L. (2007). Metodologi Penelitian Kualitatif. Yogyakarta: PT Remaja Rosdakarya.

Nurjamiaty. (2015). Pemerolehan Bahasa Anak Usia Tiga Tahun Berdasarkan Tontonan Kesukaannya Ditinjau Dari Kontruksi Semantik. Jurnal Edukasi Kultura, 2(2).

Owens, R. G. (2008). Organizational Behavior in Education (4th Ed) III. New York: Allyn\&Bacon.

Rahardi, K. (2001). Sosiolinguistik, Kode, dan Alih Kode. Yogyakarta: Pustaka Pelajar.

Roni, N. S. (2016). Panjang Rata-Rata Tuturan Anak Usia 2 Tahun 7 Bulan Dalam Bingkai Teori Pemerolehan Bahasa Anak. Jurnal Pendidikan2016.

Salnita, Y. E., Atmazaki, \& Abdurrahman. (2019). Language Acquisition for Early Childhood. Jurnal Obsesi, 3(1).

Smith, A. (2010). Development of Vocabularry and Grammar in Young America Speaking Children Assessed with aAmerica Language Development Inventory.

Sumarsono. (2013). Sosiolinguistik. Yogyakarta: Pustaka Pelajar.

Sumarsono, \& Partana, P. (2018). Sosiolinguistik. Yogyakarta: Pustaka Pelajar.

Vissiennon, K., Friederic, A. D., Brauer, J., \& Wu, C.-Y. (2016). Functional organization of the language network in three- and six-year-old children. Neuropsychologia. 